\title{
De livløse ensomme
}

Gigantiske anstrengelser, resultat lig nul Edgar Quinet - 1862

Aldrig har nogen fest vakt en så livsalig forventning, aldrig blev nogen fejret med så megen gloede

Jules Michelet - 1853

I et afsnit af sine Barndoms- og ungdomserindringer, offentliggjort i 1876, få år efter Pariserkommunens rædsler, fortæller Ernest Renan, den frække og velskrivende religionshistoriker, om en gådefuld skikkelse, der færdedes på hans hjemegn i Bretagne. Han holdt sig for sig selv og levede af at leje bøger fra sin store bogsamling ud til folk, der gad læse dem. Det var bøger af bl.a. Voltaire og Rousseau, den store filosofi og samfundskritik fra årene før revolutionen. Folk kaldte ham "System", fordi han engang havde fors $\emptyset \mathrm{gt}$ at forklare dem noget. De havde ikke forstået det, men ordet system var forekommet flere gange, og nu hed han bare "System". Efter hans død, engang efter 1830, opk øbte gejstligheden hans bøger for at lade dem destruere, men intet sted i hans fattige kammer fandt man noget, der kunne kaste lys over hans tidligere liv. "Det eneste, man fandt i en krog", skriver Renan, "var en buket tørrede blomster, omhyggeligt indsvøbt, sammenbundet med et trefarvet bånd. Man troede først, det var et kærlighedsminde, og flere spandt af denne tråd den ukendtes roman, men det trefarvede bånd usandsynliggjorde en sådan hypotese. Min moder troede aldeles ikke, at det var den virkelige forklaring. Skønt hun havde en instinktiv respekt for "System", sagde hun altid til mig: "Det er en gammel terrorist. Jeg bilder mig undertiden ind, at jeg har set ham i 1793, og desuden ligner han af udseende og anskuelser M., som terroriserede Lannion og holdt guillotinen i gang, så længe Robespierre var ved magten."

Mange år senere støder Renan på en avisnotits om en original, der er død i Faubourg Saint-Jacques i Paris: "Han var respekteret i kvarteret som et mønster 


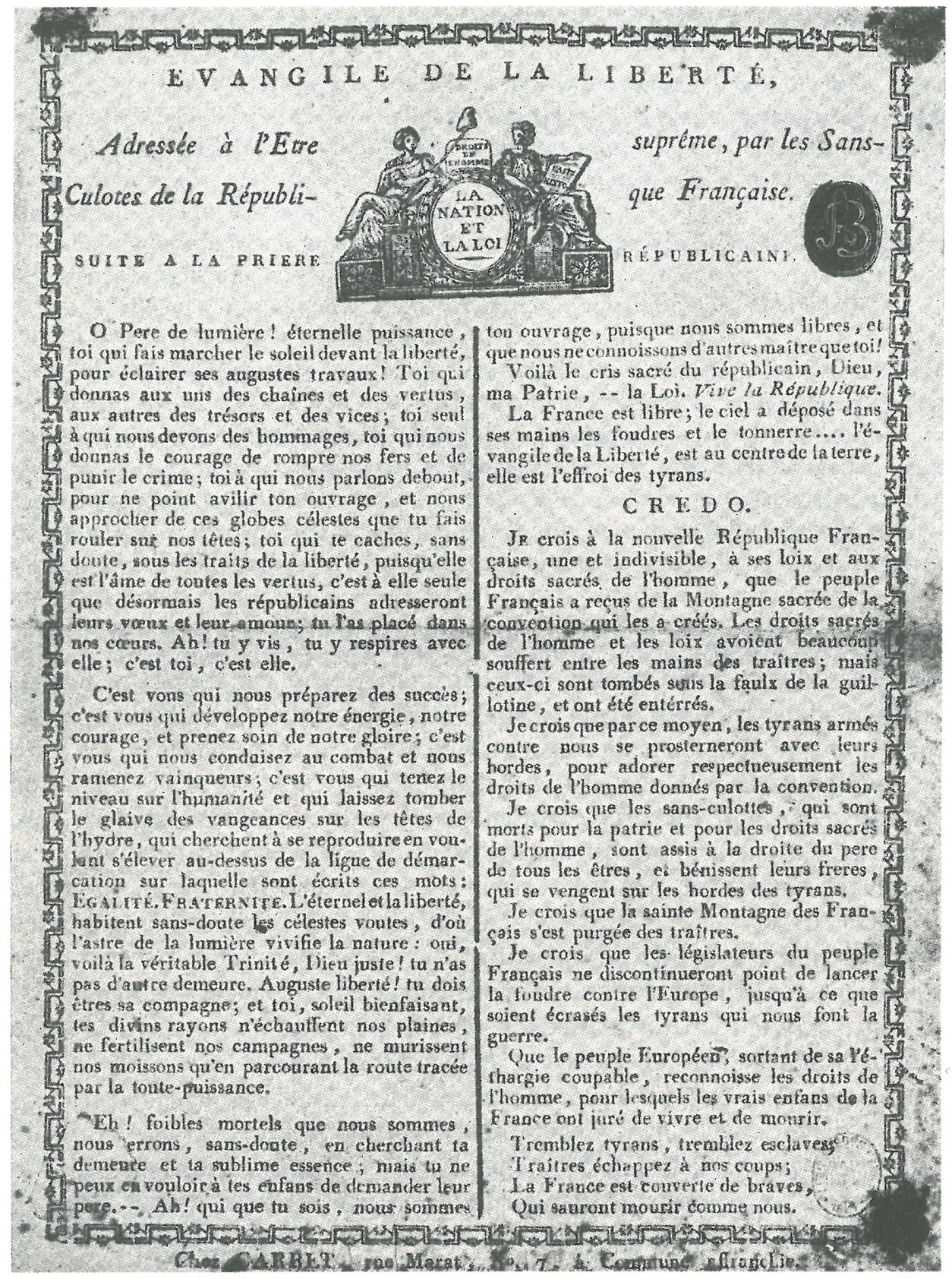


på velgørenhed og godhed, men han undgik alt, hvad der kunne lede på sporet af hans fortid. Nogle bøger, Volney's katekismus og nogle umage bind af Rousseau, lå spredt på bordet. En kuffert indeholdt al hans ejendom. Politifuldmægtigen, som blev tilkaldt for at åbne den, fandt kun nogle ubetydelige ting, hvoriblandt en vissen buket, omhyggeligt indsvøbt i papir, hvorpå der var skrevet: Den buket, som jeg bar ved festen for det højeste væsen den 20. prærial år II." Renan fortsætter: "Der gik et lys op for mig. Jeg tvivlede ikke på, at "Systems" buket stod i forbindelse med det samme minde. Jeg tænkte på de sjældne medlemmer af Jakobinerkirken, som jeg havde haft lejlighed til at lære at kende, deres brændende overbevisning og deres grænseløse kærlighed til minderne fra 1793 og 1794 og deres mangel på evne til at tale om andet. Denne drøm, der kun varede eet år, var så voldsom, at de, som havde gennemgået den, ikke mere kunne vågne. De vedblev at være under en fiks idés magt, tungsindige og bedrøvede, de havde delirium tremens af en blodig rus. De var fanatisk troende. Den verden, som ikke mere var i samklang med dem, anså de for tom og barnagtig. Da de var de eneste tilbageblevne som resterne af en verden af kæmper, der bar menneskeslægtens had, var det dem ikke mere muligt at have noget samkvem med de levende."

'68 blev muliggjort af tre faktorer, der var vævet ind i hinanden, og som samlet også havde den effekt at frembringe en bestemt bevidsthed, som var vores, var min dengang.

For det første viste kapitalismen sit hæslige fjæs hver aften på fjernsynsskærmen i skikkelse af Vietnamkrigen. Hvor udbytningen i produktionen ikke rigtig var synlig og konkret for de fleste af os, var den (ny)koloniale udsugning, som den manifesterede sig i fattigdommen og sulten i u-landene, og dens radikalisering til en imperialistisk krig anskuelig, moralsk oprørende, næsten håndgribelig. Og hvad mere var: det var muligt at kæmpe imod imperialismen, sætte en magt op imod den, der var båret af et folks fælles beslutsomhed og offervilje. Imperialismen var en papirtiger, det var blot at få de rigtige sakse frem.

For det andet viste maj 68 i Frankrig, at revolutionen var mulig i et højtindustrialiseret kapitalistisk samfund. Hvad der startede som en protest mod, at piger og drenge ikke måtte besøge hinanden på studenterkollegierne, accelererede til universitetsmanifestationer og politiets besættelse af Sorbonne, til uroligheder i Latinerkvarteret (hvor politiets brutalitet og vildskab blev formidlet en direct til nationen via de meget aflyttede radiostationer Europe 1 og Radio Luxem- 
bourg) og eksploderede i strejker og demonstrationer, der mest af alt havde karakter af arbejderopstand. I op mod en uge var statsmagten i realiteten holdt op med at fungere, selv ordensmagten, politiet, truede med at gå i strejke; magten lå der, lige til at samle op, hvis der havde stået en tilstrækkelig stærk og beslutsom politisk organisation klar. Udgangen på den historie forudsættes bekendt, men hvad vi kunne lære af den var, at modsætningen mellem kapital og lønarbejde var intakt som tilforn, at arbejderklassen ikke var integreret i det borgerlige samfund og reduceret til en forskelsløs masse af konsumenter, at revolutionen stadig stod på dagsordenen og kunne sættes i bevægelse i alle de kapitalistiske lande og det på de, hartad, besynderligste anledninger. Og at studenterne var i besiddelse af et politisk potentiel.

Endelig var den tredje hovedfaktor den højkonjunktur, der havde præget de kapitalistiske samfund lige siden anden verdenskrig, muliggjort af kapitaldestruktionen, jeg mener ødelæggelserne under krigen. Opsvinget resulterede især i 60 'erne i en voldsom forøgelse af den materielle rigdom, væksten syntes at skulle fortsætte i én uendelighed; der så ud til at være nok til alle, det var bare at dyppe snabelen. Den permanente varemassage i forbrugersamfundet og selve det stadig mere opulente forbrug underminerede tilsyneladende den gamle arbejdsog præstationsmoral, en proces, der i høj grad blev forstærket af, at der var mangel på arbejdskraft. Luther og Calvin kunne godt pakke deres arbejdsetik sammen, deres religion var vi også helst foruden. Fundamentet syntes at vakle under det gamle samfunds produktions- og konsumptionsrelationer; det gamle menneske, der levede under tvangen, selvtvangen og den bestandige udsatte tilfredsstillelses forbandelse, syntes på vej til at blive afløst af en ny mennesketype, der erstattede det tvangsmæssige arbejde på andres kommando med en frit skabende aktivitet, afviklede den restriktive atomisering og individualisering, der var afledt af markeds $\varnothing$ konomien og overlevelseskampen, og forstod sig som en del af et fællesskab. Det var et fællesskab, som det selv opsøgte og var med til at udvikle, et fællesskab, der skulle tilintetgøre den monogame spændetrøje i parforhold og ægteskab og udvikle kollektive seksuelle former, hvor seksualiteten ikke blev forstået som blot og bar genital seksualitet, men som en seksualitet, der formede og tilfredsstillede den hele krop, det hele menneske. Et frihedens rige syntes at åbne sig for mennesket - frihed i arbejdet, frihed i konsumptionen, frihed i seksualiteten, frihed sammen med andre mennesker, ikke i kamp og konkurrence med dem. Hvorfor vente og udsætte. We want the world and we want it now. 


\section{III}

Hail! Hail! rock ' $n$ ' roll, deliver me from the days of old;

Long live rock ' $n$ ' roll, the beat of the drums loud and bold.

Rock! Rock! rock ' $n$ ' roll, the feeling is there, body an' soul.

USA kom først ud af depressionen gennem krigsproduktionen og den heldigt gennemførte krig på andre landes territorier og trådte efter krigen frem som det ubetinget førende land i den vestlige verden. De nye konsumptionsmuligheder og potentielt nye frihedsmuligheder manifesterede sig først her og frembragte, også, vort århundredes store kunst, rockmusikken, der i sin frihedshunger og vildskab kun kan sammenlignes med Højromantikkens.

Rockmusikken har sit udspring i den amerikanske arbejderklasse og indoptager andre undertrykte lags musik, specielt de sortes blues, men først nu bliver musikken elektrisk, offensiv, fremaddrivende, grænsesprængende. Den har ikke, overhovedet ikke, got the blues. I sin første fase retter den sig i sit tekstlige udtryk primært mod underkuelsen og undertrykkelsen hos far og mor og i skolen og kræver frihed til et konsum og en musik - rocken selv - der er tæt vævet sammen med seksualiteten (hurtige biler, barer, damer - f.eks. Chuck Berry's Johnny B. Goode, Sweet Little Sixteen, School Days, No Particular Place To Go). I en senere fase, der kan dateres til 1967-69, hvor rocken som beat bliver annekteret af lag i middelklassen og bringes ind i et ungdoms- og studenteropr $\varnothing$ r, kræves et maksimum af livsfylde og en frihed, der bliver stadig sværere at indholdsbestemme, samtidig med at den proces, hvorigennem vi grundlæggende bliver formet til det, vi er - opdragelsen eller socialiseringen - åbner sig for analyse, kritik. En ophævelse af den psykiske tvang, som fortiden har udviklet, bliver en nødvendighed. Begge dele, livsbegæret og bevægelsen mod individuel "psykisk" frigørelse, manifesterer sig på en anden led i stofkulturen, der på sin side altid er musikkens ledsager. I de år blev der frembragt en musik, der først var moderne, som udsprang af, formulerede og forstærkede den samfundsmæssige bevægelse, der var i gang, langt fra den borgerlige kunstmusiks sterile knirken, den røde armés sangkors populistiske skrål, jazzens oldingetrut. Man bliver helt høj af at tænke på det: Steppenwolf, Doors, Jefferson Airplane, Janis Joplin, Jimi Hendrix, Procol Harum - og også Beatles, Beach Boys, Rolling Stones, Velvet Underground, på dispensation Bob Dylan. Den musik var ekstremt nærværende og lovede alt: "Hvorfor glemmer man derover, at musikken fordobler glade og sørgmodige følelser, ja endog selv skaber dem, og mere almægtigt og voldsomt end nogen anden kunstart uden overgang på et $ø j e b l i k$ river os frem og tilbage mellem glæde og smerte - jeg siger, hvorfor glemmer man en højere ejendommelighed ved den; dens hjemveens kraft, ikke en hjemve 
efter et gammelt forladt land, men efter et ubetrådt land, ikke efter en fortid, men efter en fremtid."

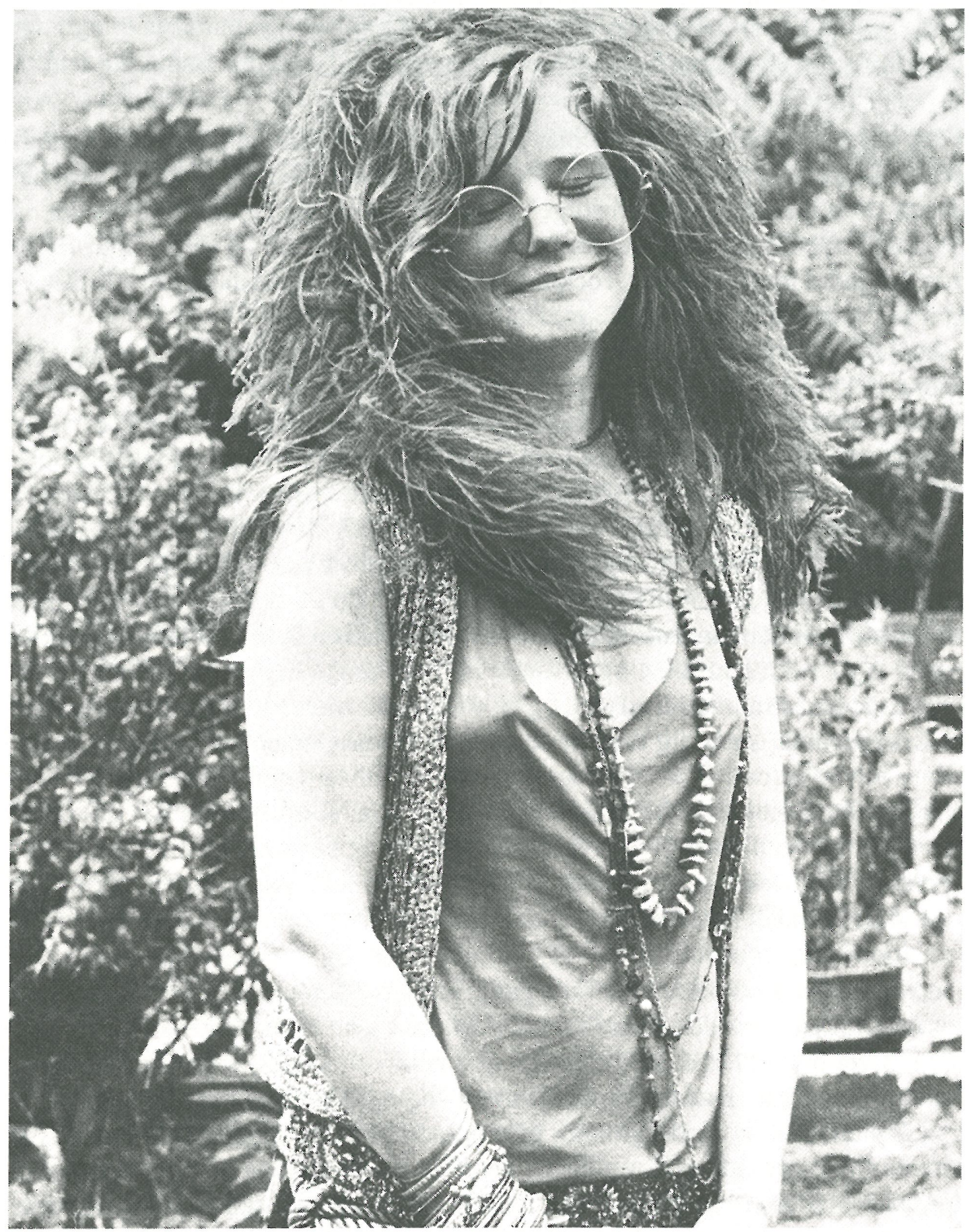

Welche Seele solche Träume schlummert, die träumt sie ewig fort, auch wenn sie erwacht ist. 
Der stod vi så på universiteterne så at sige bevæbnet med Vietnamkrig, majoprør, højkonjunktur, musik og hvis det gik vildt til Marx' ungdomsskrifter i Villy Sørensens udgave. K.B. Andersen ville have intelligensreserven frem, samfundet krævede flere højtuddannede og universiteterne ekspanderede voldsomt. Hvor universitetet før havde været forbeholdt borgerskabet og højere embedsmænds børn, eventuelt de liberale erhvervs, favnede man nu gerne børn fra småborgerskabet og mellemlag, sågar nogle fra arbejderklassen. Dengang kunne man leve af U.U. - Ungdommens Uddannelsesfond - og i sommerferien kunne man sagtens få arbejde. I det hele taget kunne man med en mindre indsats rejse nogle penge, hvis man var flad. Som studerende havde man en betydelig frihed, vel specielt i de humanistiske fag. Hvis man ikke gad gå til timer den uge, kunne man vente til næste uge, eller måned eller år, det hed sig jo at faget var baseret på selvstudium. Eksamen var langt væk, arbejde og stilling lysår borte.

Frihedstrangen voksede ikke ud af den største nød, den frihed, der rent faktisk eksisterede, avlede begæret efter og kravet om mere frihed. Det er betegnende, at studenteroprøret herhjemme startede på de institutter, hvor den reelle frihed var st $\varnothing$ rst - psykologi og de humanistiske fag. Hvad der begyndte som utilfredshed over forældede studieordninger, tåbelige professorer og krav om medindflydelse, forenede sig hurtigt med de mere gennemgribende momenter i den bevægelse, der var under udvikling: protesten mod Vietnamkrigen som kapitalistisk barbari; erfaringerne fra Frankrig om en revolutionær opstand mod det kapitalistiske samfund og dets borgerskab; erkendelsen af den voksende rigdom i de vestlige industrilande som hvilende på kapitalistisk udbytning. Hertil kom et mindre klart formuleret behov for at kaste den ham af os, som vores ofte småborgerlige baggrund og opvækst i et kapitalistisk samfund havde trukket ned over os. Så meget desto større var det følelsesmæssige pres, loengselen efter at ophæve de (små)borgerlige karakterstrukturer, som det efterhånden var sivet ind i knoppen på os, at vi rent faktisk var bærere af midt i vores mere og mere revolutionære elan. På én led søgte vi efter (ringe) evne at befri os fra individualisme og konkurrencestræb, opløse det dengang berømte Marcuse'ske præstationsprincip og lave noget i fællesskab, i grupper, på en anden led med st $\varnothing$ tte i musikken, der rummede et enormt emancipatorisk og seksuelt potentiel, at få bevægelse i karakterstrukturerne, helst ved fest efter fest, hvor der var en del sprut, mindre hash, men mange damer og herrer, der var hooked på seksualitetens frigørelse.

Hvad der var startet som en partikulær kritik af universitetet blev potenseret til en total kritik af det kapitalistiske samfund og det kapitalistiske menneske med en ledsagende mere improviseret terapi. Kritikken af samfundet hentede skyts fra 
Frankfurterskolen (Adorno, Horkheimer, Habermas, Marcuse) og senere Marx forsøget på at forstå alt det gamle bras, vi bar rundt på, satte af fra Freud, Marcuse (Eros and Civilization - uforglemmelig) og Wilhelm Reich, den samme Reich, som havde givet stødet til de første ansatser til oprør mod den seksuelle repression, sådan som den manifesterede sig i kønsadskillelsen på de franske studenterkollegier. På det teoretiske plan blev der gjort forarbejder til tre vigtige landvindinger: den senere Kapitallogik, det dristigste, bedst funderede og mest radikale fors $\emptyset \mathrm{g}$, der er gjort på at videnskabeliggøre kritikken af det kapitalistiske samfund, hvad man så ellers kan mene om den; den fortsatte beskæftigelse med psykoanalysen og endelig det material- og socialhistoriske opbrud, som det bl.a. har materialiseret sig i arbejderhistorie, kvindehistorie, seksualitetshistorie, fængselshistorie, ak, the hour's getting late, dødshistorie. - På det praktiske plan under den efterhånden permanente fest kunne man konstatere, at nogle røg gennem loftet og var med Jimi Hendrix helt oppe og kysse himmelen, nogle trak sig hurtigt tilbage under ordnede forhold, mens andre tilsyneladende ikke rigtig havde opfattet radikaliteten i den frihedslængsel, som omstændighederne havde gjort mulig. Men de samme omstændigheder havde ikke muliggjort indløsningen af kravet om frihed.

Oprøret i 68 fadede ud, fordi det manglede et tilstrækkeligt materielt fundament. På de områder, hvor der var basis for det, fik vi vores krav igennem. Men en del af det, der i vore hoveder var højst subversivt, var samfundsmæssigt ikke andet end en højst nødvendig omformning: nye studieordninger, medbestemmelse som led i en modernisering af universitetet.

De franske studenters heltegerninger kunne ikke i længden dække over det faktum, at de - og vi - ikke var centralt placerede i produktionen, at vi slet ikke var i produktionen, at det var ganske uden betydning for samfundets funktion om et par tusinde humanister, psykologer og kultursociologer hoppede rundt og råbte slagord mod onde Helge. Og hvis man ikke var helt ekstatisk, kunne man næppe undgå at bemærke, at arbejdere og andre folk, der gik på arbejde hver dag, havde et ret skarpt blik for de reelle privilegier, vi besad, for vores fremtidige funktion $\mathrm{i}$ kapitalens eller statens tjeneste, og for den enorme afstand, der var mellem vores liv, livsførelse og tankegang og deres. Det blev selvfølgelig ikke bedre af, at de eliteprægede træk i vores fremfærd var åbenbare. Vi drømte om en revolution, men med os selv som ledere. De senere så elitære sekter (ja, jeg har selv været medlem af et par stykker), der forfægtede leninismens principper, nemlig at arbejderklassens korrekte bevidsthed skal tilføres udefra af dem, der forstår, intelligensen, som også skal lede den revolutionære proces - er kun ét belæg for, at det rent faktisk forholdt sig sådan, selv om folk dengang ikke var meget for at indrømme det, når det blev bragt på bane. Det må dog retfærdigvis noteres, at disse studentikose fors $\emptyset \mathrm{g}$ på at annektere arbejderklassens liv og virkelighed blev 
imødegået af det værdifulde samarbejde mellem universitetsfolk og arbejdere, der trods alt blev etableret: De fagkritiske rapporter - Malerrapporten m.fl.

Vores frihedskrav overskred langt, hvad der var samfundsmæssigt muligt på det tidspunkt, for vi fløj på lette vinger hen over de politiske nødvendigheder og realiteter. For det første manglede den politiske kraft ganske i Danmark, der kunne bryde vej til og udvikle det socialistiske samfund. Det samfund, vi som i et syn så indskrænke nødvendighedens rige - arbejdets og produktionens - og udvide det frihedens rige, der er forudsætningen for skabelsen af det nye menneske, det fuldt udviklede menneske. Hvad der var mulighed og på vej til at blive realitet i Robespierres fædreland, var ikke engang mulighed i Grundtvigs. - For det andet var det plat umuligt at gennemføre en revolution i Danmark alene; Danmark var og er tæt integreret i den vestlige verden - økonomisk, politisk og militært. For det tredje var vi reelt isoleret i forhold til andre sociale bevægelser, specielt arbejderbevægelsen, bl.a. fordi vi brugte en ikke ringe energi på at hakke løs på reformismen og klassesamarbejdet, specielt på Socialdemokratiet, men også på DKP og fagforsteningen. Med rette, men dette kunne selvfølgelig ikke fremme samdrægtigheden.

Og for det fjerde var vores klassebasis højst labil, nærmest ikke-eksisterende. Vores sociale, politiske, klassemæssige bevidsthed var grundlagt og udviklet under vores socialisering, vores opvækst, opdragelse, skolegang - vores egentlige "klassebevidsthed" havde sit fundament her, i hvad vi havde gjort og især hvad der var blevet gjort ved os i de første godt tyve år af vores liv. Det, der var kommet til, den kolossale omvæltning i vores måde at tænke og opfatte tingene på, og også i den måde, hvorpå vi oplevede dem og følte dem, var muliggjort af ovennævnte vigtige faktorer i samfundsudviklingen (og selvfølgelig også andre) - havde i den forstand et reelt materielt grundlag. Men alt det nye lejrede sig, bl.a. fordi det hele gik så fandens hurtigt, oven på vores rent faktisk eksisterende bevidsthedsform, den bevidsthed, der ikke var udviklet på tre måneder, men på tyve år. Derfor blev vores revolutionære sindelag i den grad præget af idealisme, voluntarisme, kompromisløshed og svævede smukt hen over den faktiske personlighed, der mere eller mindre var gået i dækning, men som reelt var bestemmende for den småborgerlige radikalisme, der prægede tankegange og begivenhedsforl $\varnothing \mathrm{b}$ og styrede vore handlinger.

Vores bestræbelse på gennem fuldførelsen af et universitetsstudium at nå op i en samfundets elite, der ikke tidligere i samfundsmæssig målestok havde været åben for medlemmer af de sociale lag, vi kom fra, skiftede under begivenhedernes tryk karakter til at være en bestræbelse på at manifestere sig internt i den revolutionære bevægelse. For senere at stivne i fantasien om det partiforberedende arbejde - drømmen om via sekterne at opbygge det revolutionære parti, der med de nu blodrøde studenter som "kadrer" skulle indgyde masserne "klassens" 


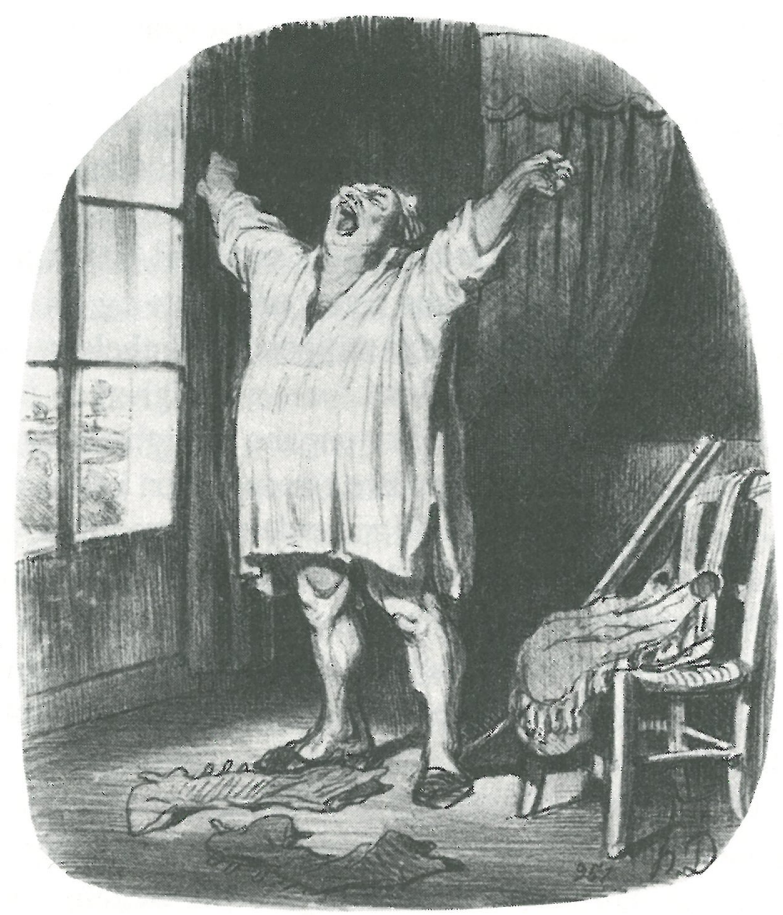

Kandidatmedlem

bevidsthed udefra for senere at bemægtige sig statsapparatet og omdanne det til proletariatets formål under proletariatets diktatur. Det var næsten for morsomt. Jeg gentager dette moment, for i arbejderismen og det verdensrevolutionære storhedsvanvid opgav vi endelig det særlige liv og den særlige virkelighed, der var vores.

Jeg tror, at revolutionen, på globalt plan, var mulig i 68, som den var det i 67 og 73 og er det i dag. Det virvar af årsager og bevægelser, der betinger en revolutionær situation og dens videredriven til produktionsmådens fald, revolutionen, er umuligt at analysere sikkert og korrekt, mens det står på. Hvem kan bedømme de tilfældigheder, der set under en anden vinkel er nødvendigheder, og som udløser dette gigantiske samfundsmæssige jordskred. Post festum, når virkeligheden har bekræftet eller dementeret alle spekulationerne, kan også Maren i Kæret og Georg Gearløs se, at det var muligt eller umuligt. Men hvad vi for vores del var i gang med, var ikke en revolution, ej heller forløberne for en sådan - hvad der lavede en helvedes larm, var en rebellion, og deltagerne var rebeller. Opflammede af lidenskab var de klar til at smadre verden i en kamp, der ofte men aldrig kun det - hentede sin energi og dynamik fra konflikter udviklet i fortiden. Da verden viste sig betydelig mere træg end fantasien og lidenskaben hav- 
de forudset, tabte rebellerne den smule kraft og udholdenhed, de var i besiddelse af. Fantasien blev sat fra magten. Hvad der startede som en erobring af kloden endte i kapitulation. Not with a bang but a whimper.

I Wagners "Siegfried" vandrer Wotan, der endelig har opgivet sig selv, usalig rundt på jorden i skikkelse af en tigger, der er bevæbnet med vandringsstav, bredskygget bulehat, fuldskæg og briller. Adorno bestemmer i sit essay "Versuch über Wagner" den faldne gud i denne småborgerlige apparition som den, der ynkeligt er faldet fra himlen ned på jorden og nu slæber sig af sted bærende på resterne af 1800-tallets småborgerlige og pseudorevolutionære bevægelser fra studenterorganisationerne, Burschenschaften, og gymnastikstrategen Turnvater Jahn til de senere "tyske socialister", som Marx gør sig lystig over: "Af deres opstand er spøgelsesagtigt intet blevet tilbage andet end deres blotte fremtræden. Wotan er den begravede revolutions fantasmagori. Han og hans lige går som spirits rundt på de steder, hvor dåden mislykkedes, og deres kostume fastholder tvangsmæssigt og skyldbevidst mindet om det fors $\emptyset$ mte øjeblik i det borgerlige samfund..." Den, der alene ved egne kræfter, på et ikke tilstrækkeligt samfundsmæssigt, politisk og ikke mindst personlighedsmæssigt fundament mente sig i stand til at stige højere og højere, "kiss the sky", "take the world in a love embrace", rebellen, blotter sig i sit fald som simpel tigger: "I det truende billede af tiggeren er rebellen bevaret: som bedende har han indrettet sig borgerligt i Bohêmen. Men at dette billede glider over i billedet af guden vil først og fremmest sige, at den, der er blevet gjort afmægtig som tigger, tidligere var guden, nemlig at han tidligere var i besiddelse af chancen til at forandre verden, en chance, som han mistede; men også at rebellen, idet han viser sig som gud, selv er gået over til autoriteten og repræsenterer den verden, som han skulle have forandret." Konklusionen ligger lige for: "Forræderiet er rebellionen selv iboende."

\section{VI}

Disse åndsh $\phi v$ dinge ivrede undertiden mod despotiet, og de modtog løn fra despoterne.

Hvad der blev forstået som revolution, afslørede sig som rebellion og fandt endelig sin virkelighed i simpelt forræderi. Det var ikke et forræderi, der blev 
udløst af moralsk svigt. Det var et tragisk forræderi, som det ikke længere så nye venstre blev drevet ud i under forholdenes tvang.

Det er mig en gåde, at den del af venstrefløjen, der i sin tid studerede Marx' mange blå bind, ikke for længst har givet et mere hidsigt bud på venstrefløjens forfald. Det allerførste vers i salmen lød dog: "Det er ikke menneskenes bevidsthed, der bestemmer deres væren, men omvendt deres samfundsmæssige væren, der bestemmer deres bevidsthed." Vores revolutionære lidenskab og frihedstrang var på et helt konkret materielt plan muliggjort af en velvillig, omend undrende stat, der tilvejebragte vores økonomiske eksistensgrundlag, alt imens den tålmodigt afventede tingenes normalisering. Midt i vore studier af Marx og Habermas og Marcuse og Lukács havde vi ganske glemt, at det, vi var ved at uddanne os til, var stats-embedsmænd. Vi kunne i søvne, at staten var den herskende klasses stat og instrument, men ikke desto mindre vandrede vi med søvngængeragtig sikkerhed i gabet på den store Molok, der æder alle børn, også revolutionens. Dér stod vi et par år efter med koner og mænd og børn og en kæmpe studiegæld. Hvis vi ikke inden for en overskuelig fremtid skulle synke ned i pjalteproletariatet eller i det mindste se frem til at gå den tunge gang til socialen, måtte vi indlevere en ansøgning i tre eksemplarer til den selv samme stat, som vi vidste i sidste instans tjente kapitalens interesser, den stat, der om nødvendigt ville sætte alle magtmidler i bevægelse for at hindre frigørelsen af proletariatet, af os selv - i den livssituation, vi nu var - umuliggøre den befrielse af menneskeheden, som vi havde set i vore drømme og håb.

Nedværdigelsen var selvfølgelig ikke overstået med den simple ansøgning. Der kom de mange dage, hvor vi måtte udføre et arbejde, som vi et eller andet sted var klar over var behæftet med undertrykkelse, ja usandhed. Dagene blev til år, og vores identitet blev efterhånden eroderet bort og erstattet af en art kompromisets og legitimeringens identitet. Den uendelige bortforklaring tog den plads op, hvor der ikke længere var håb. Vores alderdomstegn fremstod mere og mere som tegn på en moralsk forfaldsproces. Skaldepanderne, hængerøvene, de grå hår, rynkecremerne myldrede som djævle frem på jord ved 1. maj-fester og lignende arrangementer, bærende på pjalterne fra det fejlslagne oprør dengang. Postulatorisk begærede de at bekræfte deres solidaritet med de undertrykte i $\emptyset$ st og vest, jo mere eksotisk, jo bedre, vel vidende at de i deres arbejde fra dag til dag modarbejdede de selvsammes liv og forhåbninger. Hvad der engang var beruselse i håbet om befrielse, var nu blot en fylderiets dødedans. Hvad der engang var en seksualitet, der ville fri som led i en større befrielse, var nu blot det nødtørftige lokumsknald med naboens moster.

Videre: De blå bind havde belært os om, at statsapparatet blev finansieret gennem merværdi. Hvor arbejderen nu som tilforn har en sikkerhed og en fortrøstning i bevidstheden om, at han rent faktisk producerer, hvad der er 
fornødent til hans livs opretholdelse, hans værdi, og at han herudover er objekt for kapitalens overgreb i form af inddragelsen af den merværdi, som han også producerer, dér var vi usikre på, hvorfra midlerne til vores livs opretholdelse hidrørte. Den efterhånden mangedoblede bevidsthed om, at vi modarbejdede samfundsgrupper, som vi ideologisk hævdede at solidarisere os med, at vi måske levede af deres arbejde, at vi $i$ virkeligheden udnyttede og lod os udnytte af det borgerlige samfund, vi påstod, vi ville bekæmpe - gled umærkeligt over i en forfaldets og undergangens bevidsthed. Ét sted fremstod den verden, der havde lukket sig for os og trængt den enkelte tilbage i sig selv, drømmeagtigt som labyrintisk, uigennemsigtig, uden centrer og overgribende strukturer. På et ejendommeligt følelsernes nulpunkt fandt mange sig til rette i denne tilstand, uden smerte, uden sorg, og indrettede sig borgerligt i Bohêmen, alt imens de uddrog en middelmådighedens lyst af tingenes og andre menneskers Schein, der nu modstandsløst lod sig substituere. Men et andet sted vendte det vilde håb om et kollektivt liv tilbage i mareridtet om den kollektive død. I kampen mod atombomben blev der temporært vakt et mål af kraft og modstand, men hos mange kunne indsatsen mod den kollektive død næppe skjule det kollektive dødsønske, kampen for at afværge døden som den enkeltes død, den ensomme død. Angsten for atombomben var og er selvfølgelig først og fremmest fremkaldt af den frygtelige trussel, som specielt USA's afsindige oprustning og korstog mod kommunismen med overtoner af renselse og dommedag udgør, men den henter utvivlsomt næring fra oplevelsen af den sociale død. Det ubestemte ubehag, kvalmen i et liv, der aldrig vil kunne indfri vores forventninger, opfylde vore krav om moralsk integritet, endsige virkeliggøre vores drømme, finder sit billede og udtryk i rædselen for den individuelle død, der igen glider over i det sammenhængende politiske mareridt omkring atomdøden og den kollektive død. Kollektiv drøm, kollektivt mareridt og i sær forvrænget form sidste kollektive politiske aktion.

Hvad de par arbejdere, vi fik støvet op på værtshusene i 68, havde forudsagt, var rent faktisk gået i opfyldelse. "Når I bliver færdige, står I på den anden side, og giver ikke en skid for os." F $\phi r$ de anklagede frem: Der er de koleriske revolutionære, der $1 \varnothing b$ vildt fægtende rundt i sekterne og råbte: Knus det borgerlige statsapparat. Et par år efter lod de sig ansætte på handelshøjskoler, universiteter, gymnasier, hvor de nu fører unge mennesker op til eksamen. Der er de kritiske psykologer, der fik sat kasketten godt på plads og nu sidder som skolepsykologer og sorterer proletarbørn og andre fra til en afvigerkarriere og i en ejendommelig moralsk-scientistisk diskurs giver dem den næstsidste olie, inden de skal vandre videre ud i nye nederlag, nye nedture, menneskelig ruin. Eller deres studiekammerater, der sidder på de psykiatriske hospitaler og laver prøver og skriver erklæringer, ja mentalerklæringer, medens deres kolleger, de crazy psykiatere, 
kigger dem over skulderen og brummer bifaldende og lover kun at tage den fornødne tvang i anvendelse. Der er de alternative, de blegrøde teologer, der nu for skatteborgernes penge holder prædikener, der hverken kan støde gud eller fanden, og som både sanktionerer at man kommer ind i livet, at man sørger for at det går videre, efter evne, og at man kommer ekspres ud af det. Der er de subversive jurister og $\emptyset$ konomer og politologer, der nu høvler rundt i ministerialkontorer og kommunaladministrationer. Der er de insurrektionelle medicinere, der nu møvrer sig opad i hospitalshierarkierne. Nu skal vi jo heller ikke blive for statsfikserede: Der er de salige, der er faret lukt til himmels i erhvervslivet, og som må tillægges en vis respektabilitet, så længe de både producerer værdi og lader sig udbytte. Nogle arbejder for den lille kapital, andre for den store, nogle sågar for den multinationale. Enkelte fossiler kan beses i fagforsteningen. - Jeg hører stemmer: Tat-twam asi - det er du. Jeg er om ikke den tapre landsoldat, så dog menig i reservearmeen. Som led i en århundredgammel strategi modtager jeg en underst $\varnothing t t e l s e$, der skal afholde mig fra at tilskynde til eller deltage i sociale uroligheder eller noget, der er endnu mere uhyggeligt. Strategien synes at være ganske vellykket. Jeg spiser af den samme hånd som fodrer andre, der lever af stat og kommune.

\author{
O, wie himmelblau ist mir zu Mut' \\ Schnaps schmeckt besser als Futter, \\ Dann schimpft auch meine Frau, ich sag' schon gut \\ Heut' ist alles in Butter, Mutter.
}

\title{
VII
}

Som årene gik fortonede 68 sig mere og mere som en fjern drøm, som en ungdoms vildfarelse, resultat af højkonjunkturen. I takt med at de nu gode borgere lod sig prostituere offentligt, i takt med at deltagerne fra at være ærefrygtindgydende veteraner i deres bestandige forræderi og svaghed fremstod som mere og mere grinagtige, lukkede erindringen sig, og folk krøb sammen i det, der nu engang var blevet deres liv. Deres liv nu tabte forbindelsen til deres liv dengang, 68 blev på én og samme tid afskrevet og mytologiseret som anno mirabile, erindringen om dengang som et led i vores liv, som kun muliggjort ud fra den aktuelle livssituation, vi stod i, gik i stumper og stykker - som hukommelsesbrokker om den og den fest, det og det møde, demonstration, bog, det og det knald. En umulig nutid opslugte og tilintetgjorde fortiden. 


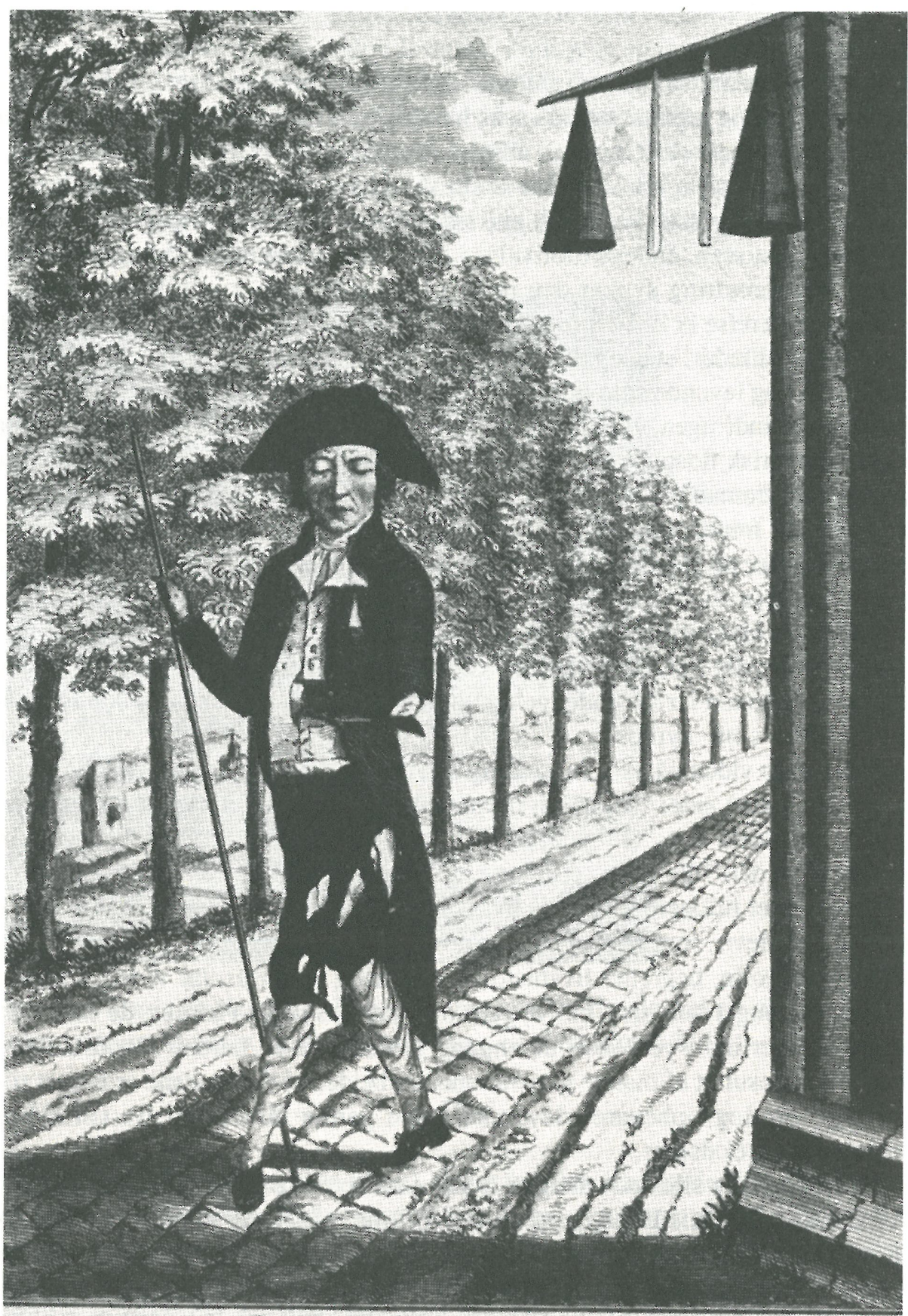

Émigrand. Resenant. a.Paris. 


\section{VIII}

Efter at verdensånden har haft tålmod og kraft til at udføre "verdenshistoriens uhyre arbejde" og nærme sig side seks hundrede, ser den sig i de sidste passager af Phänomenologie des Geistes, i absolut forvisning om at være sig selv bevidst og mægtig, rede til at vriste sig løs af sin slyngen sig om sig selv og frembringe tid, rum, natur og historie. Er den ene side af dens eksistens natur og verden, er den anden historien, åndens tilblivelse i tiden. Her antager den skikkelsen erindring. Som erindring synker den ned i selvbevidsthedens nat, hvor dens forsvundne tilværelse er opbevaret, skriver Hegel. Denne forsvundne tilværelse er et galleri af billeder, et anegalleri - af mennesker, af slægter, af samfund, der er d $\varnothing \mathrm{de}$, men dog levende som opbevarede i erindringen og som erindrede levende realitet for erindringen, eller dem, der erindrer, selvfølgelig. Ånden begynder på et givet historisk tidspunkt forfra, men gør det dog kun tilsyneladende, for den bevæger sig fremad på grundlag af, hvad alle tidligere "ånder", dvs. mennesker, samfund, har frembragt. Således følger "ånder" på "ånder", mennesker på mennesker, slægter på slægter, samfund på samfund, men idet mennesket erindrer, muliggøres den forståelse, der kan uddrages af historien, af det uhyre arbejde, der har skabt historien og de konkrete historiske forl $\varnothing$ b. Historien bliver menneskets historie, det medium, i hvilket dets liv og frihed virkeliggøres. Historien begribes, og ånden får sin endelige og højeste fremtræden og frihed i den begrebne historie som syntesen af, hvad Hegel kalder videriskaben om den fremtrædende viden på den ene side og den empiriske historie, der forløber i tiden, på den anden side: "begge tilsammen, den begrebne historie, er erindringen og den absolutte ånds Golgata, dens trones virkelighed, sandhed og vished, uden hvilken den ville være det livløse ensomme..."

Således lever tidligere slægtleds liv, vores egen fortid, videre i os som materiel realitet, som levn, som fantasier, som ubevidste erindringer, men sjældent som begrebet historie, begrebet livshistorie, erindring som absolut viden. Vi bor i huse, som længst henfarne har bygget og pyntet, synger i kirker, de har rejst, drages i bøger ind i verdener, de engang gav skikkelse, færdes i landskaber, i byer, der er resultat af mange generationers arbejde. - I den voksne er barnet tilbagelagt, og dog opbevaret, levende; i den gamle får et helt liv sin sidste fremtræden og eksistens.

"Traditionen fra alle døde slægter hviler som en mare på de levendes hjerne", skriver Marx i "Louis Bonapartes attende Brumaire". Det er i denne mareridtets nat, vi ofte synker ned, fordi vi ikke forstår, hvad der er sket, historien, og vor egen livshistories indlejring heri. De afdøde slægter, der vandrer gennem hjernen, antager kun fremmede og skræmmende skikkelser som ikke forståede, ikke bevidste, som døde, lig, der nægter at lade sig indføje som bestanddele af det le- 
vende. For den menneskelige historie, menneskelivets sandhed og paradoks er, at det døde er dødt, og dog endnu levende, biologisk og historisk, så sandt som jeg, som ethvert menneske er bærer af materiale fra liv, der blev levet, længere og længere tilbage i tilværelsens lange kæde - så sandt som jeg i dette øjeblik sidder og blader i en bog, der er skrevet i 1806, en bog, der som oplevet realitet, læst af mig, kan manifestere sig i en bred vifte af helt konkrete materielle livsudtryk, som at jeg f. eks. taler om den, skriver dette ned, bliver bevæget. Jeg er her, og dog er de till stede.

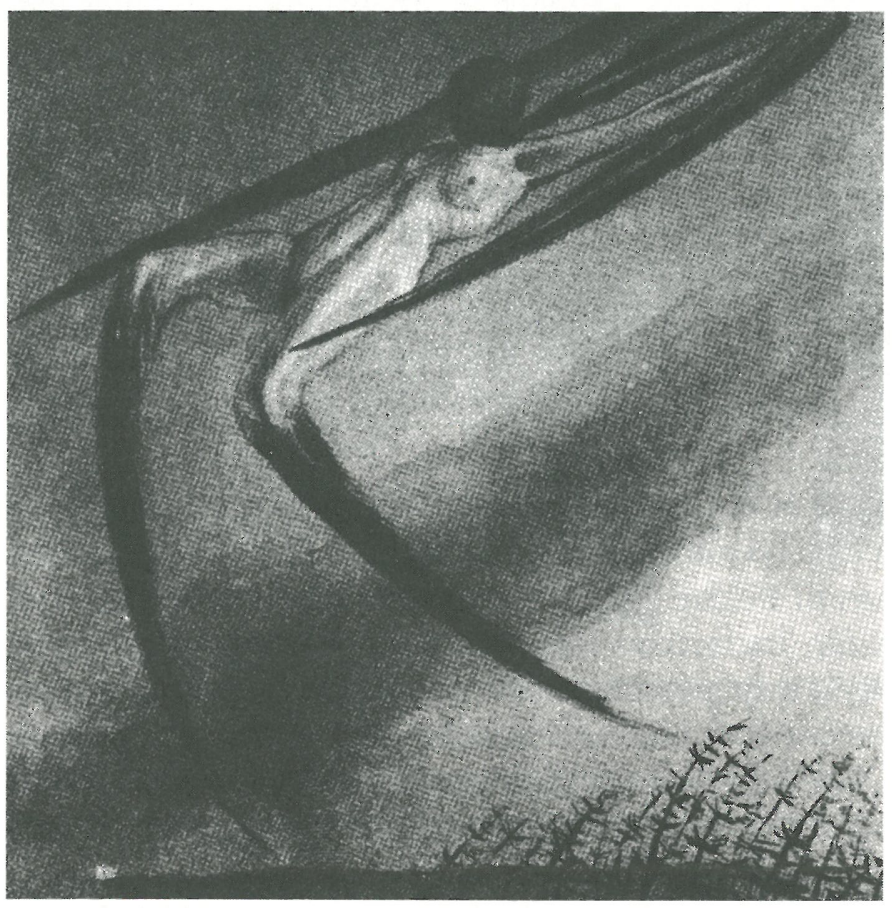

"Hver nat kommer der en drøm"

Sært forvågede er de døde. Ene, i skarer skaffer de sig vej til de levende og søger varme ved deres liv, før de med dem, til sidst, finder hvile.

\section{IX}

Fremmed, svøbt i glemselens kåbe vender fortiden hærgende tilbage - menneskehedens som skæbne, forfærdende dårskab, en endel øs række af ødelæggelser og grusomheder - vor egen som tvang, tilfældigheder, fejltagelser. Men livet afsætter sine spor, der fører tilbage til det, der var, og også omvendt fremad til det, der er nu. Hvad der skete dengang, hvad vi gjorde, hvad der blev gjort ved os, er ovre, forgangent og dog opbevaret i os som noget, der er der, som altid vil 
være der. Kunne jeg blot glemme. Men kan jeg eller ønsker jeg nogensinde at glemme festen, begæret, helikopterne over Vietnam, de sultendes smil, de mærkelige forkrøblede, dem, der tog deres eget liv. Og meget mere.

At det overhovedet var muligt at drømme drømmen lover for, at den engang vil blive indløst. Den indbyrdes afhængighed og samhørighed mellem mennesker på jorden, som kapitalen med dens verdensmarked og alt det andet har gjort til virkelighed, rummer netop muligheden for, forudsætningen for opkomsten af en ny medmenneskelighed - ikke sendt fra himlen, men skabt af menneskers eget liv og arbejde gennem de bånd, som udvekslingen af arbejdsprodukter, alles indbyrdes afhængighed lægger på os - som forpligtelse, som en befrielse. Jeg er mig og dog de andre. I mig, også, har de andre deres liv. Hvad der allerede er realitet, bliver først til frihed, når handlingen har frembragt bevidstheden, og bevidstheden har gjort handlingen til en livsnødvendighed. Her skal slaget stå. I kampen for den endelige virkeliggørelse af en historisk udviklet, ny udformning af medmenneskelighed, mod alle historisk overhalede snævre og nu $\emptyset$ delæggende tanke- og livsformer - egoisme, solipsisme, individualisme, nationalisme, hvorfor fortsætte denne triste række. I en mægtig bevægelse stiger tilstedeværelsens dag frem fra mulighedens nat eller menneskers liv synker ned i tilintetgørelse for altid.

I den politiske vurdering er det håbløst at lade sig hypnotisere af det korte tidsstræk, en periode på bare tyve år. Var den galning, der i 1829 forudsagde Julirevolutionen, blevet fø̆t til Bicêtre eller la Salpêtrière? Hvem havde forudset 1848-revolutionen året før, Pariserkommunen på verdensudstillingen i Paris 1867, ja, for den sags skyld majoprøret hundrede år efter i et land, hvor den historiske erindring og bevidsthed om disse perioder med kampe om produktionsmådens liv og død, med potenseret liv, stadig er så levende, at republikkens præsident har Michelets gamle revolutionshistorie liggende på sit natbord? Hvad der måske ikke lykkes for os, fordi vi ikke forstår, ikke orker, fordi vi svigter, kan lykkes for dem, der følger efter. For os, herfra hvor vi står, sidder, ligger, må kravet være anstcendighed - overtage og fastholde vores livshistorie, som den er vævet sammen med andre menneskers - ansvarlighed over for andre mennesker, de andre, som er betingelsen for, at vi overhovedet kan eksistere som mennesker, hvilket, formuleret som næstekærlighed - som Baudelaire skriver - ikke blot er et spørgsmål om moral, men om god smag. Og om at forsøge at handle derefter, offensivt - om man tør bruge det udtryk - i al beskedenhed fors $\emptyset$ ge at trække i den rigtige retning, ophævelsen af menneskers beherskelse af andre menneskers liv og defensivt, hvad der kommer ud på det samme, nægte at modtage ordrer fra borgerskabet og dets følgagtige håndlangere, der i deres vulgære materialisme og aggressive grådighed og havesyge er på vej til at forvandle denne smukke og mærkværdige klode til en massegrav. 


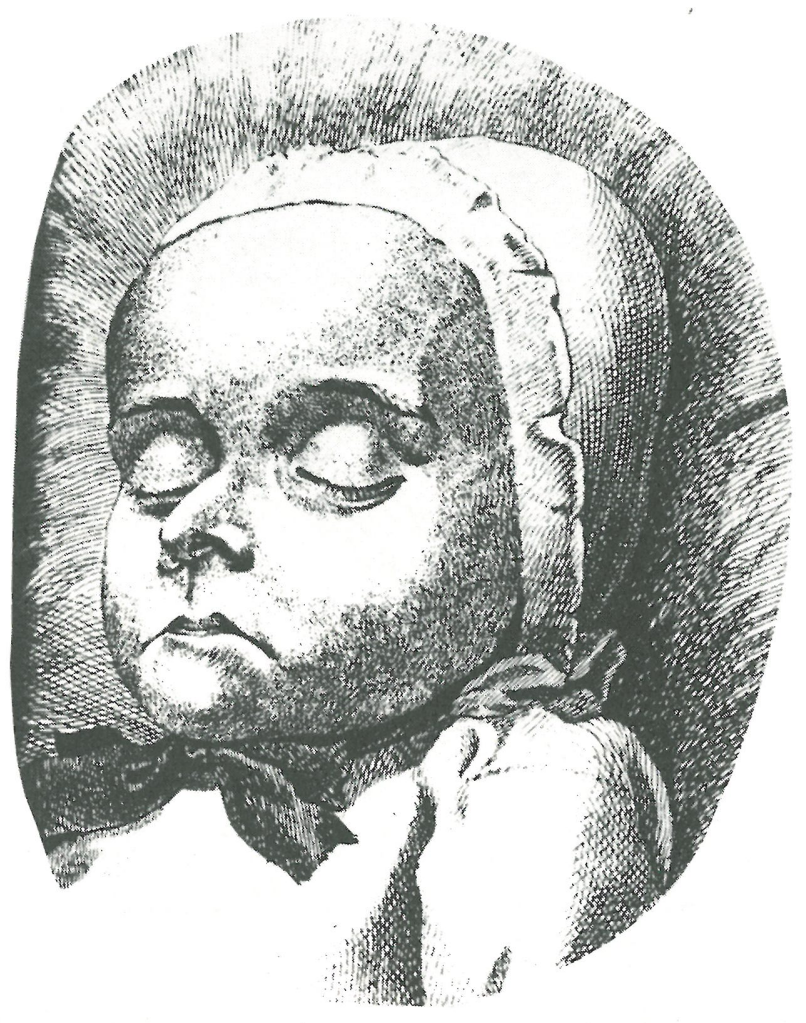

The days are cold, the nights are long, The north-wind sings a doleful song;

Then hush again upon my breast; All merry things are now at rest, Save thee, my pretty Love!

The kitten sleeps upon the hearth, The crickets long have ceased their mirth;

There's nothing stirring in the house Save one wee, hungry nibbling mouse, Then why so busy thou?

Nay! start not at that startling light;

'Tis but the moon that shines so bright On the window pane bedropped with rain:

Then little Darling! sleep again, And wake when it is day. 
$\mathbf{X}$
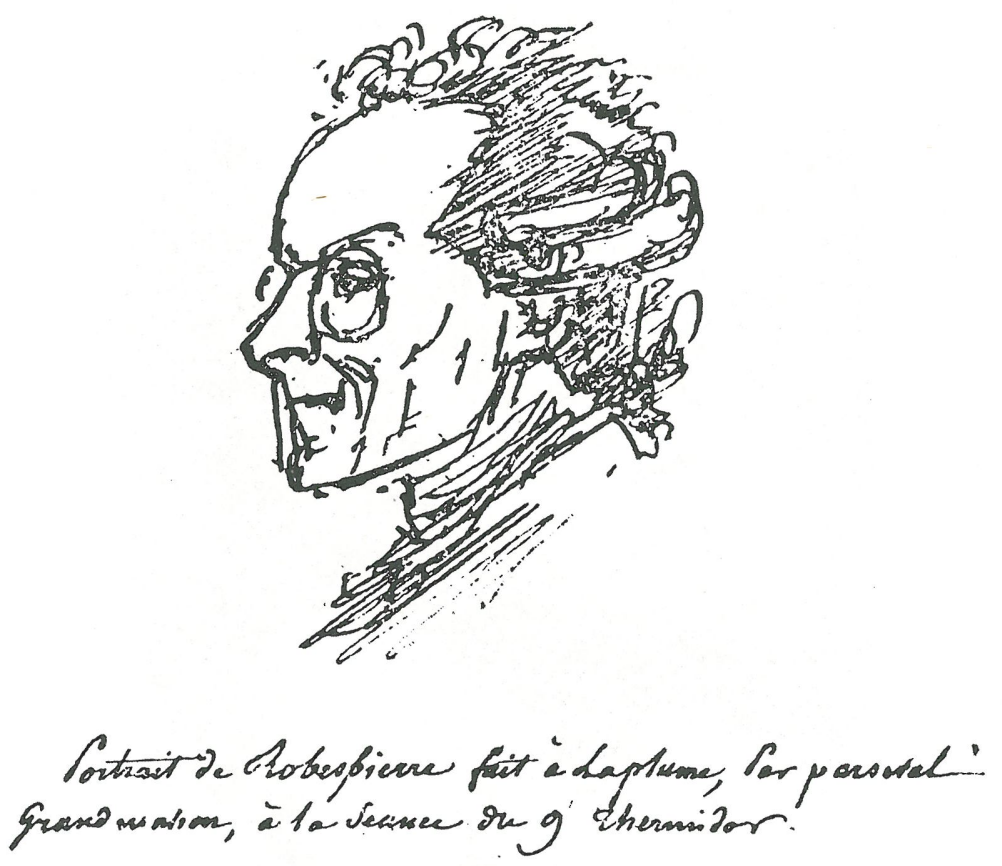

"Den franske republik fejrer hver tiende dag med fester som følger: 1: For det højeste væsen og naturen. 2: For mennesket. 3: For frihedens martyrer. 4: For friheden og ligheden. 5: For republikken. 6: For verdens frihed. 7: For fædrelandskærlighed. 8: For hadet til tyranner og forrædere. 9: For sandheden. 10: For retfærdigheden. 11: For blufærdigheden. 12: For æren og udødeligheden. 13: For venskabet. 14: For frugtbarheden. 15: For modet. 16: For ærligheden. 17: For heltemodet. 18: For uegennytte. 19: For stoicisme. 20: For kærligheden. 21: For den ægteskabelige troskab. 22: For faderkærligheden. 23: For den moderlige ømhed. 24: For datterkærlighed. 25: For barndommen. 26: For ungdommen. 27: For manddommen. 28: For alderdommen."

\section{XI}

"Lad os indstifte en mere bevægende fest, festen for ulykken: slaverne tilbeder den gode skæbne og magten; vi, lad os ære ulykken; ulykken, som menneskeheden ikke fuldstændig kan fordrive fra jorden, men som den trøster og lindrer med respekt!" Afsindige håb, umådelige trods. Nu omsider, i den nye tidsalder, 
er mennesket rede til, i stand til at overtage dets liv i alle dets bestemmelser, triumferende $\mathrm{i}$ festen for ulykken at bemægtige sig og menneskeliggøre de tilværelsesvilkår, der i hele menneskeslægtens historie har stået forstenede og fjendtlige over for mennesket som naturtvang, biologisk nødvendighed, tilfældighedernes spil, skæbne. Først nu, hvor menneskers beherskelse af mennesker er ophørt, bliver menneskets verden menneskeverden, menneskelivet menneskers sande ejendom. Først nu, hvor herrerne er tilintetgjort, bliver mennesket herre i dets eget liv i alle dets dimensioner. Og i en fornuftens passion indstifter Robespierre de følgende fester til arbejdet, til historien, til fremtiden for endelig at indvie den fireogtredivte og sidste fest til det, som det først var historisk muligt at frembringe som politisk krav i oplysningstiden, som revolutionen satte på dagsordenen for to hundrede år siden, som i morgen, engang vil finde sin virkelighed. - "30: For landbruget. 31: For industrien. 32: For vore aner. 33: For eftertiden. 34: For lykken."

\section{XII}

"Aldrig har nogen fest vakt en så livsalig forventning, aldrig blev nogen fejret med så megen glæde. Guillotinen forsvandt, den 19. prærial om aftenen. Man troede, at det var for altid. Et hav af blomster (bogstavelig talt, udtrykket er ikke overdrevet) oversvømmede Paris; roser fra tyve mils omkreds blev bragt ind, og blomster af alle slags, alt, hvad der krævedes for at blomstersmykke husene og menneskene i en by på syv hundrede tusinde sjæle. Alle vinduer skulle have deres blomsterkrans eller banner. Alle mødrene bar roser, pigerne forskelligartede blomster, mændene egegrene, de gamle folk grønt vinløv. Ned mellem de to umådelige rækker, mændene til højre, kvinderne til venstre, gik

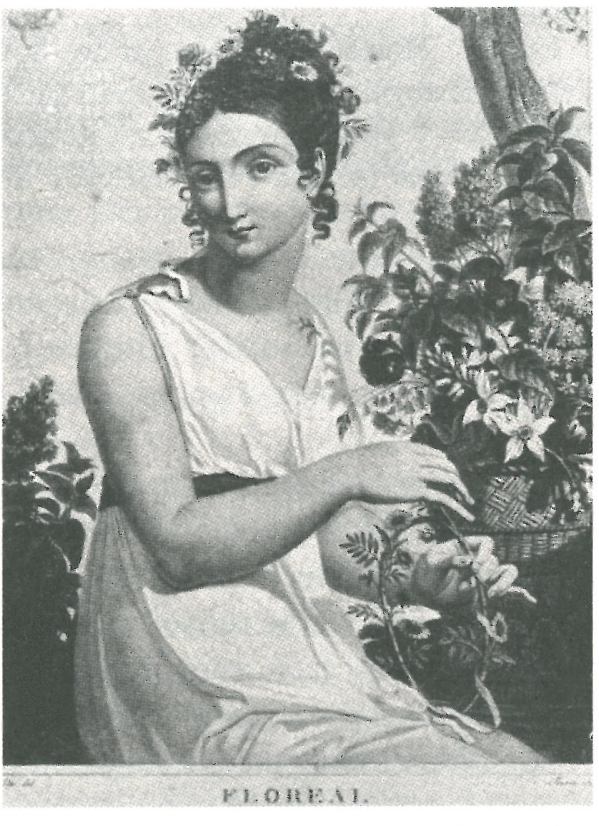
mødrenes stolthed, deres sønner, unge mennesker på femten eller seksten år, lykkelige over at bære sabler eller spyd smykket med kviste.

Disse levende floder af mennesker, disse strømme af blomster flød sammen som et hav ved Tuilerierne. Aldrig har en mere fortryllende regnbue smilet under en smukkere himmel." 


\section{Noter}

Til de første afsnit er bl.a. benyttet Jules Lund: Maj 68. Studenterbevagelsen og klassekampene i Frankrig. Citaterne i afsnit III er af Chuck Berry og Jean Paul, et stærkt par. Teksten ved billedet af Janis Joplin er fra Friedrich Schlegels "Lucinde", skrevet under indtryk af den franske revolution, men først færdiggjort til udgivelse 1799. Den fremadstræbende ung-kadre i afsnit IV optræder på Daumiers litografi: "En ung mand som er familien Badinguets håb og stolthed". Litografiet indgår i serien Les bons bourgeois.

Citatet først i VI er fra Robespierres tale til konventet 18. floréal år II (7. maj 1794). Talen er optrykt i H. Sten (ed.): Orateurs de la Révolution, Kbh. 1946. Robespierre refererer til Encyklopædisterne. De øvrige uddrag af Robespierres taler i afsnit X og XI er hentet sammesteds og endvidere fra Torben Juncker: Den store revolution dag for dag, Kbh. 1973. - Det lystige vers i VI synges af Comedian Harmonists, hvis "jødiskmarxistiske skrål" nazibanden fik kvalt.

Laveringen i afsnit VIII er af Alfred Kubin, 1901. Tegningen af det døde spædbarn findes i J.C. Lavater: Physiognomische Fragmente zur Beförderung der Menschenkenntnis und Menschenliebe, 1775-78; digtet er Dorothy Wordsworth's "The Cottager to her Infant".

Floréal - blomstermåneden - er den 8. måned (20. april - 19. maj) i den nye republikanske tidsregning, der trådte i kraft samtidig med republikkens oprettelse 22. september $1792=1$. vendémiaire år I. Sidste afsnit er uddrag af Jules Michelet: "Festen for det højeste væsen (8. juni 94)" i Histoire de la Révolution francaise, (1847-53), Paris 1939. 